at universities of Great Britain also comprised: the focus of all physician training was on increasing care about a patient, it means that treatment must become patientoriented; development of skills of future doctors to take responsibility for medical profession on matters of morality, scientific and medical ethics; to form the understanding of future doctors their connection with the society and care about the health of its members and so on).

The fifth period (XXI cent.) - reforming and modernization stage (opening of seven new medical schools four of which in England: Brighton and Sussex Medical School under Brighton and Sussex Universities, Hull York Medical School under Hull and York Universities, Peninsular Medical School under Exeter and Plymouth Universities, University of East Anglia Medical School; implementation of the program for quality assurance of medical education (QABME - Quality Assurance of Basic Medical Education) so on) [2, p. 89-91].

Considering everything, we can arrive at the conclusion that the revealed by the mentioned above scholars phases of HME development in Great Britain lead to understanding of the modern educational development peculiarities and thus let us design the higher medical institutions in such a way that their graduates will be competitive on the international job market.

\title{
References:
}

1. Dornan, T. O. (2005). Apprenticeship and the «New Medical Education». Journal of the Royal Society of Medicine, vol. 9(3), pp. 91-95. URL: https:/www.ncbi.nlm.nih.gov/pmc/ articles/PMC1079407/

2. Mahrlamova, K. (2018). Retrospectyvnyi analiz vyshchoi medychnoi osvity u Velykii Brytanii [Retrospective analysis of higher medical education in the UK]. Molod' $i$ rynok, no 2(157), pp. 86-92.

3. Palamarenko, I. O. (2012). Profesiina pidhotovka simeinykh likariv u vyshchykh medychnykh shkolakh Velykoi Brytanii: avtoref. dys. na zdob.nauk.stup.kand.ped.nauk: 13.00 .04 - teoria i metodyka profesiinoi osvity. Nats. un-t bioresursiv i pryrodokorystuvannia Ukrainy. Kyiv.

\section{PSYCHOMOTOR DEVELOPMENT OF CHILDREN 5-6 YEARS WITH DOWN SYNDROME BY THE METHOD OF SENSOMOTOR KINESIOTHERAPY}

\section{Nikol Dmitriieva ${ }^{1}$}

DOI: https://doi.org/10.30525/978-9934-588-11-2_50

Today it is proved that one of the main components that characterizes the physical perfection of the body is the level of development of motor function, which is realized in various motor activities. It is associated with all movements. Pathology of the motor apparatus or defects in the development of motor skills limit the ability of a person in daily life, choosing a profession, adversely affecting his health and

${ }^{1}$ Academician Yuriy Bugay International Scientific and Technical University, Ukraine 
psychophysical development. Optimal motor activity plays the role of a kind of regulator of the development of the child's body, a prerequisite for the formation and formation of the child as a biological being and social entity. Motor function is manifested in the management of the child's motor skills. It provides motor activity, without which the full life of children and their normal development is impossible.

Today, the problem of social rehabilitation of children with Down Syndrome is becoming more urgent, as the number of such children has a steady upward trend.

The study was conducted in the form of group sessions with children 5-6 years with Down syndrome for five weeks at the Center for Social and Psychological Rehabilitation of Children and Youth with Functional Disabilities. Classes were held twice a week. The study involved 10 children aged 5-6 years. During the study, all classes were conducted by a kinesiotherapist in the presence of a center director, a defectologist (tiflopedagog), a social educator, a practical psychologist, and parents [1].

According to the proposed method, the kinesiotherapist is engaged in improving the sensorimotor integration of mental processes in the child through the implementation of locomotor acts, manipulation of objects, «recognition» of events occurring both inside and outside the child's body. This is complemented by optimization of the affective sphere of the child. The basic idea of the proposed set of special exercises and techniques is to increase the recognition of people, their movements, individual objects in the environment, as well as the phenomena of social life by improving the overall functioning of the child's psyche.

During the implementation of sensorimotor kinesitherapy in the child at the same time 4 configurations are updated:

- the experience of one's body;

- experience of the object;

- experience of interaction with the teacher;

- holistic attention - combining the attention of the child and the kinesitherapist aimed at performing joint activities.

When conducting physical education classes by the method of sensorimotor kinesitherapy, it is recommended to follow a certain pace of training. For example, at the stage of grinding, kneading and sorting the pace is slow, and all other exercises are performed at an intense pace, without pauses between them. Particular attention is paid to the rhythm of the exercises.

Classes last about 50 minutes on average. This time can be reduced to half an hour when vegetative reactions and signs of affective overload occur. Classes are held with a constant score of up to ten to create a steady rhythmic sound structure that accompanies the exercise.

The last 10 minutes of the lesson are devoted to singing, designing, collecting large puzzles and other tasks, aimed mainly at updating cognitive functions. This is due to the fact that after the motor exercises in the child increases mental tone, and at this time optimal tasks that are aimed at developing the cognitive sphere and improve the emotional background. Children with marked negativity after motor exercises are more easily involved in joint activities aimed at the interaction between the teacher and the child. 
According to the method of sensomotor kinesiotherapy, exercises for physical education are classified according to the target orientation: exercises for optimization of the tonic component of motility in a passive way; exercises for the development of visual-motor coordination; exercises to integrate early postures and movements into more complex coordination; exercises for the development of the cognitive sphere.

Consequences of the influence of conducting classes according to the proposed method: reduction of functional hypotension, increase of diversity of activity, development of communication, development of general motor skills, development of fine motor skills, development of great motor skills and coordination of movements, perception of speech, improvement of work of the apparatus of articulation, self-care.

Thus, the results of the use of the sensomotor kinesitherapy technique in physical education classes demonstrate that it is an effective tool for improving the psychomotor functions of children aged 5-6 years with Down syndrome [1].

Children became better able to navigate space and to understand their own bodies, to respond more quickly to environmental changes and adapt to them. Their cognitive level increased, motor abilities improved (children became more motor-agile, movements became clearer, components of impaired movement coordination became smaller). With children it became easy to negotiate, to carry out more complex joint activity. The time of completion of any task (both physical and mental) and the degree of active participation in it have increased several times in comparison with the initial indicators.

\title{
References:
}

1. Dmitriieva, N. S. (2019). Vplyv zaniat iz fizychnoho vykhovannia za metodykoiu sensomotornoi kinesioterapii na psykhomotornyi rozvytok ditey 5-6 rokiv sz syndromom Dauna [Influence of physical education sensomotor kineseotherapy method for psychomotor development of children of 5-6 years with Down syndrome]. Innovative pedagogy, vol. 2, no. 13, pp. 111-116.

\section{PECULIARITIES OF TEACHING LATIN PHONETICS IN THE FRAMEWORK OF E-LEARNING: STRATEGIES AND PRACTICAL TIPS}

\begin{abstract}
Alla Kulichenko ${ }^{1}$ Yuriy Polyezhayev ${ }^{2}$
\end{abstract}

DOI: https://doi.org/10.30525/978-9934-588-11-2_51

It is believed that Latin is a dead language because there are no native speakers and the language remains unchanged. That's why proper reproduction of letter-phoneme matching and other phonetic peculiarities are impossible. However, today Latin is a

\footnotetext{
${ }^{1}$ Zaporizhzhia State Medical University, Ukraine

${ }^{2}$ National University «Zaporizhzhia Polytechnic», Ukraine 